\title{
CARTOONISTS: Campion Ohasio
}

\section{A Solomons 'voice'}

The cartoons of Campion Ohasio, former Uni Tavurcartoonist and now co-editor of the Solomons Voice in Honiara, were featured in the last special edition of Pacific Journalism Review under the title 'Ting Ting Bilong Mi'. Here are several of his cartoons on Solomon Islands issues.

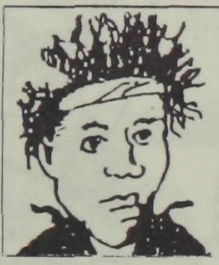

CARTOONING and cartoonists are still a fairly rare thing in the Solomon Islands - especially compared to Papua New Guinea. Solomon Islanders have yet to fully appreciate the variety, humour, flavour and message portrayed by cartoons. One reason is that cartoons are still not widely used in the country's print media.

Of the two main newspapers in the country, the Solomon Star, a bi-weekly. does not run cartoons that are locally created about local issues. It is only my paper, the Solomons Voice, that is striving to add that variety for the benefit of its readership. And it has been doing a great job because a recent survey showed that the editorial cartoon has been quite popular.

I believe Solomon Islanders will eventually enjoy the humour and variety of cartoons just as people do in Papua New Guinea - and I hope to be part of that transition. I'm not doing as much cartooning as I would like as I am so busy with the editorial side of the paper, but that doesn't discourage me.

The editorial cartoons - 'Man Talem Duim' - in the Voice are fast becoming popular and an encouraging sign for me and the handful of cartoonists the country has at present.

\section{Campion Ohasio}




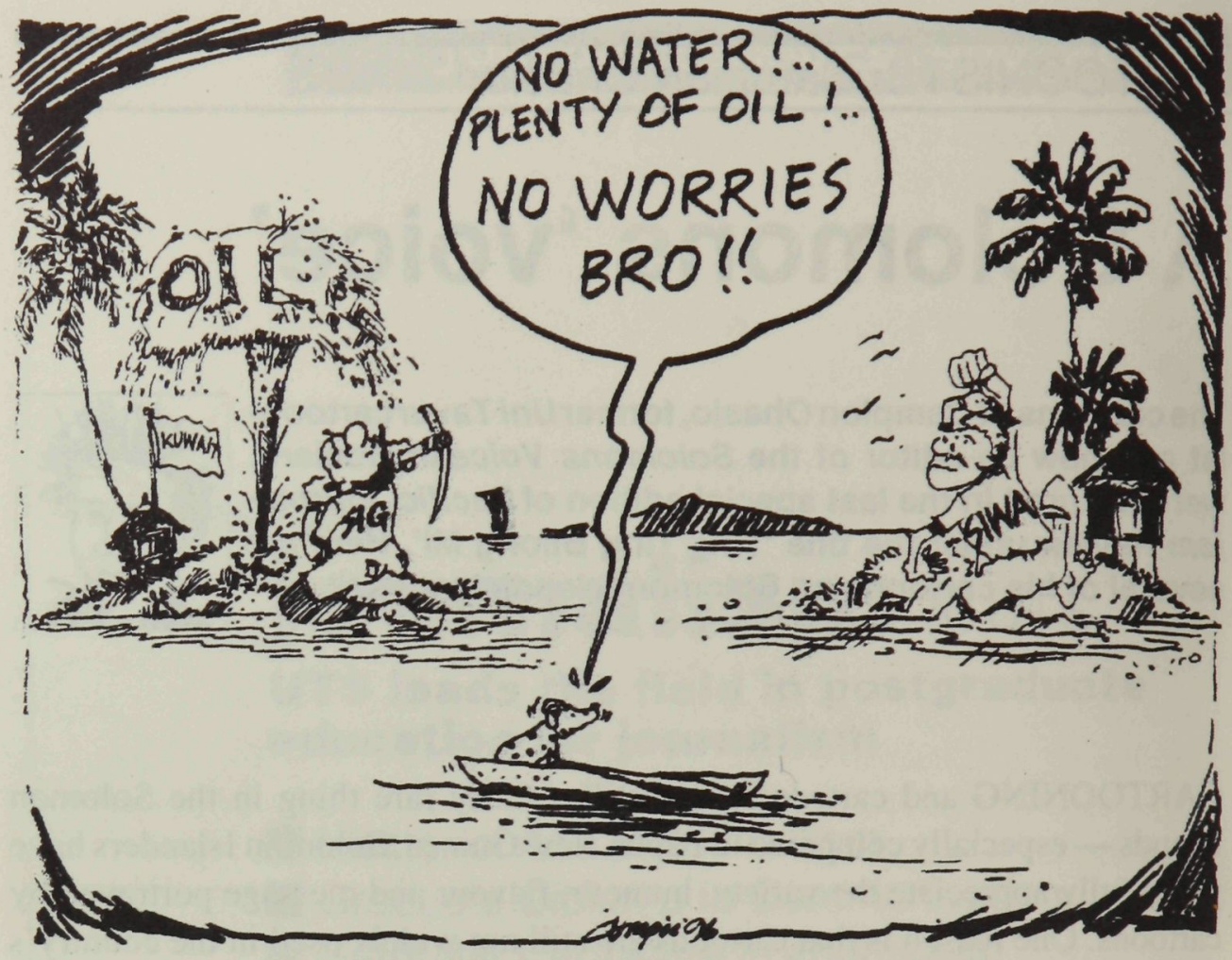

Solomons Voice, November 1995: Some Honiara residents have been without water for almost three weeks and the Solomon Islands Water Authority is relentlessly trying to solve the problem. Meanwhile, the Solomon Islands Government is concentrating on arrangements to sign an oil deal with Kuwait. 


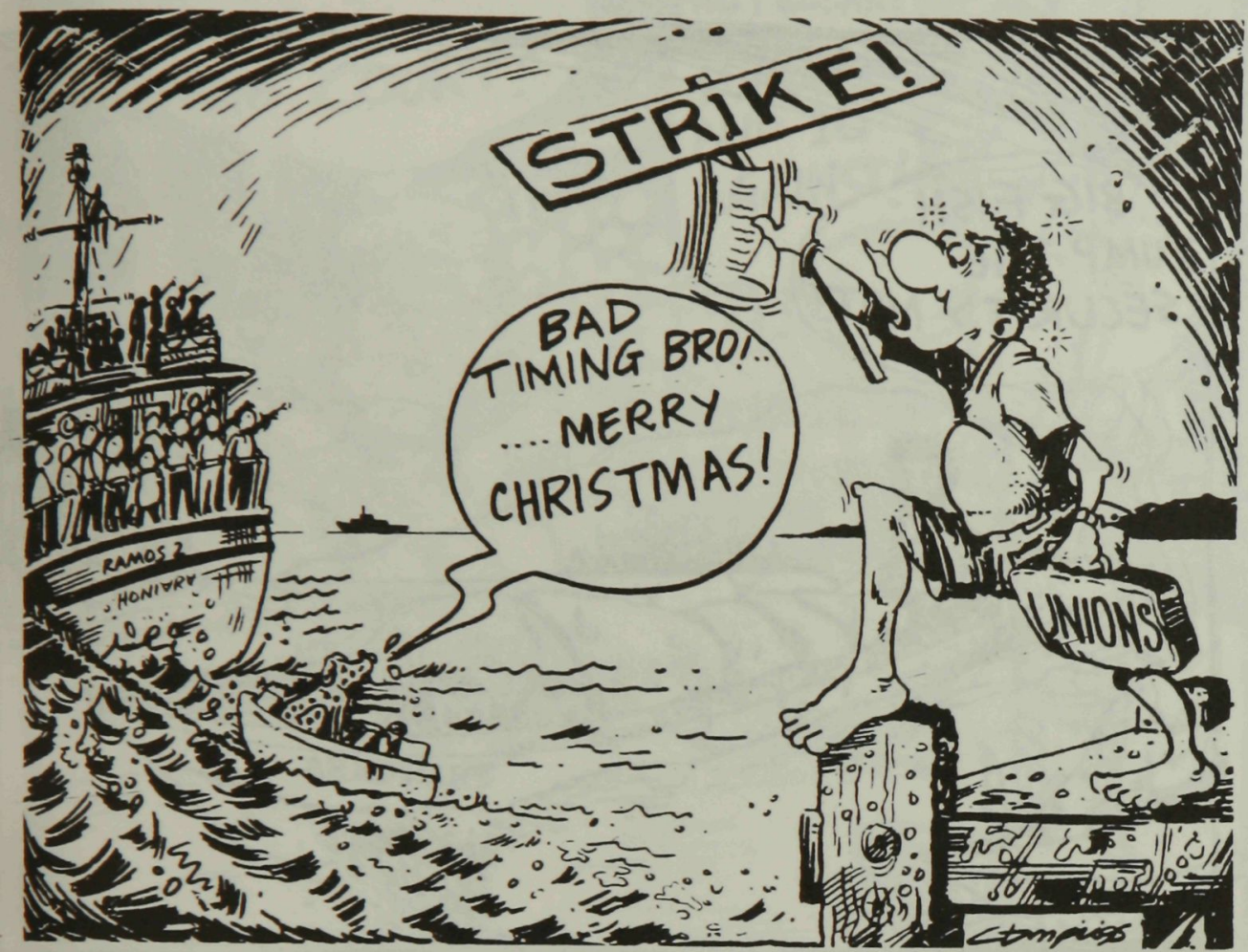

Solomons Voice, December 1995: The Solomon Islands

National Union of Workers (SINUW) called for a national strike last December. They must have known it was time for a Christmas vacation for most union members. Spotty had nothing to say about the strike - it was Christmas. 


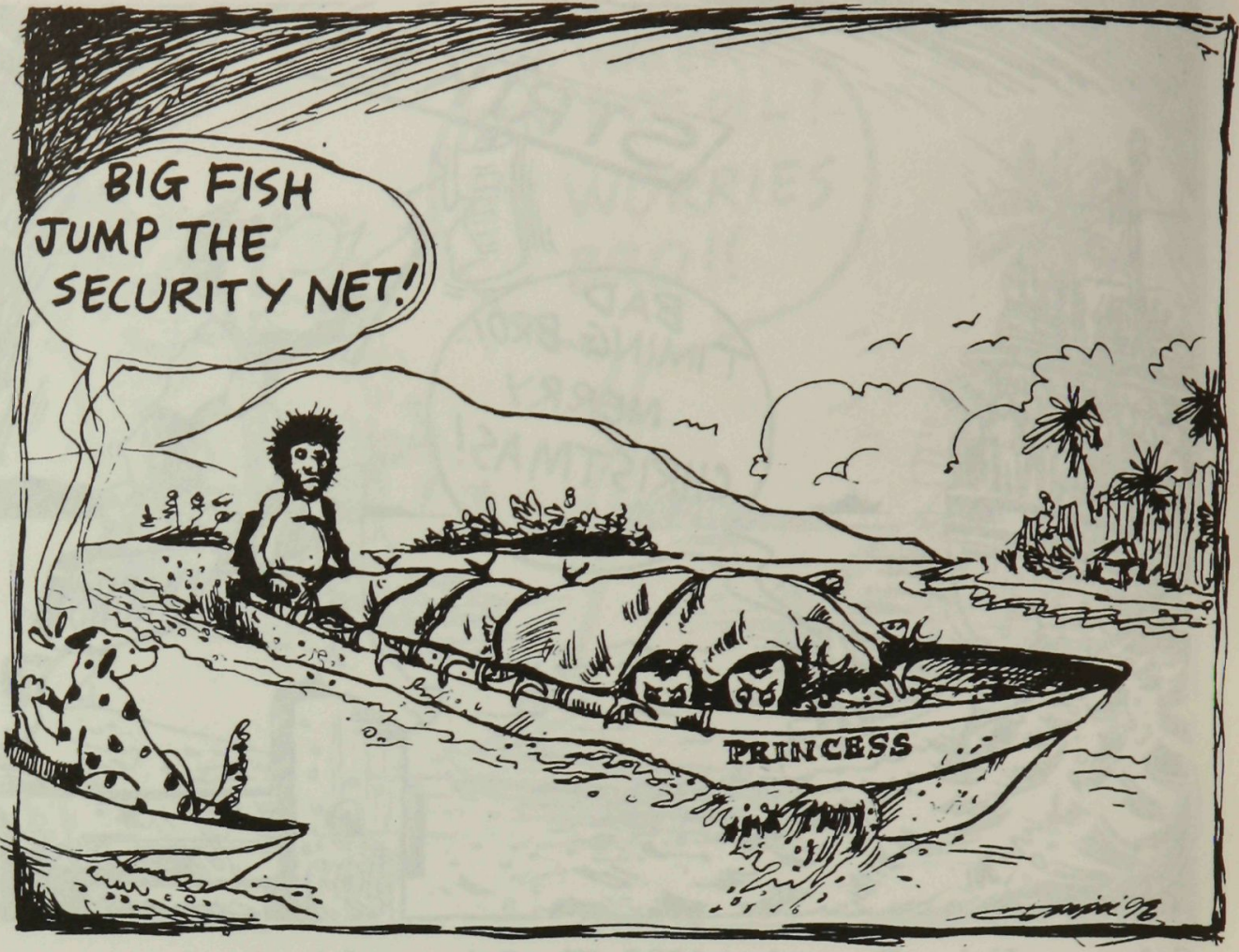

Solomons Voice, 2 February 1996: Australian human rights lawyer and Bougainville Revolutionary Army sympathiser Rosemary Gillespie and her daughter had been on Bougainville. They sneaked across the border into the Solomon Islands this week. Both were summoned to the Magistrate's Court in Honiara and deported to Australia on the same weekend. 


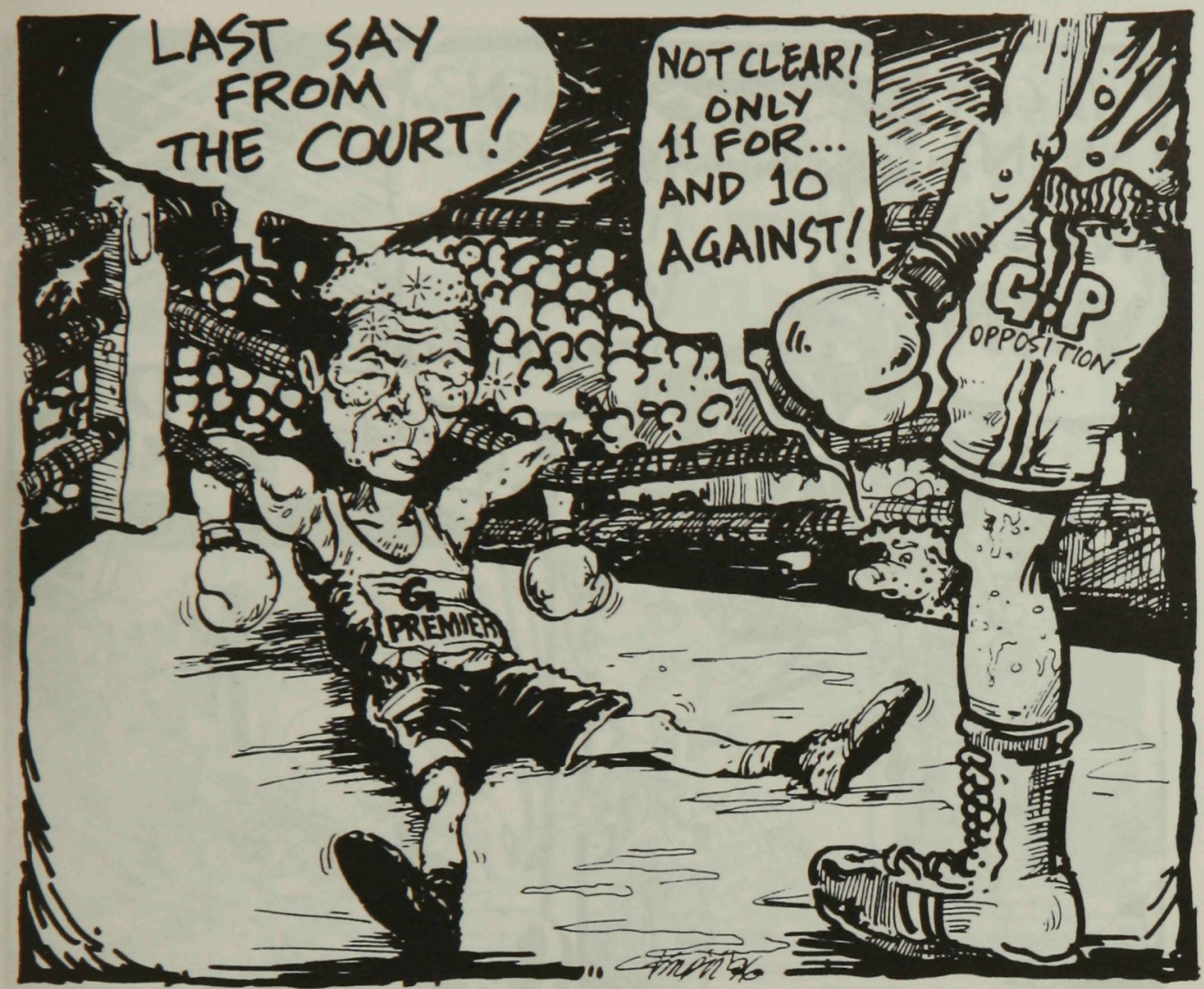

Solomons Voice, 22 March 1996: The Guadalcanal Premier, Gideon Moses, went down in a motion of no-confidence by his opposition. But he announced he would fight back in court. He later lost the fight again. 


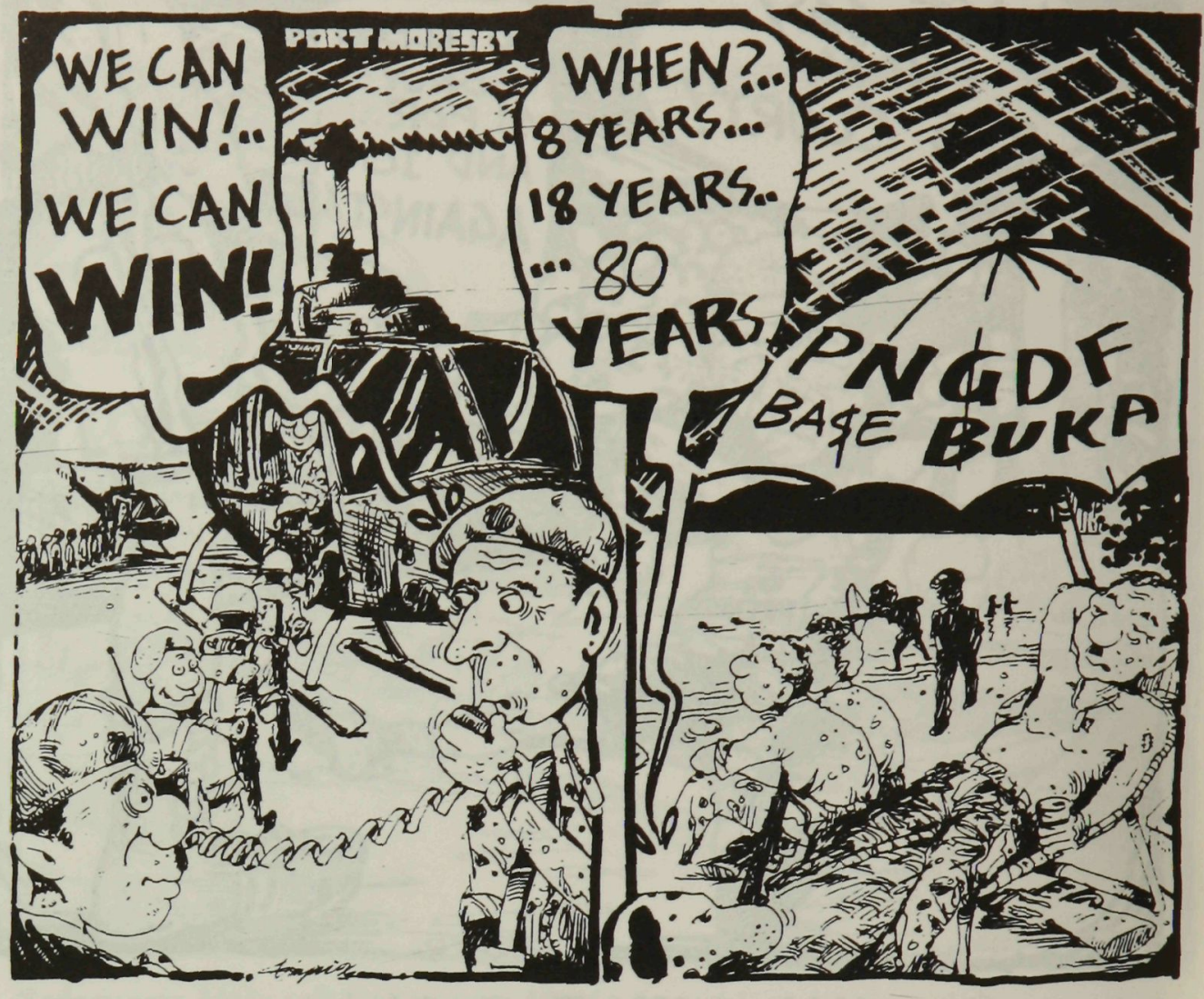

Solomons Voice, 29 March 1996: The PNG Prime Minister,

Sir Julius Chan, declared a ceasefire on Bougainville and predicted PNG could still win the war. While on the war front for the PNG Defence Force, life has been the same for the last eight years. Spotty wonders how long this war will continue. 


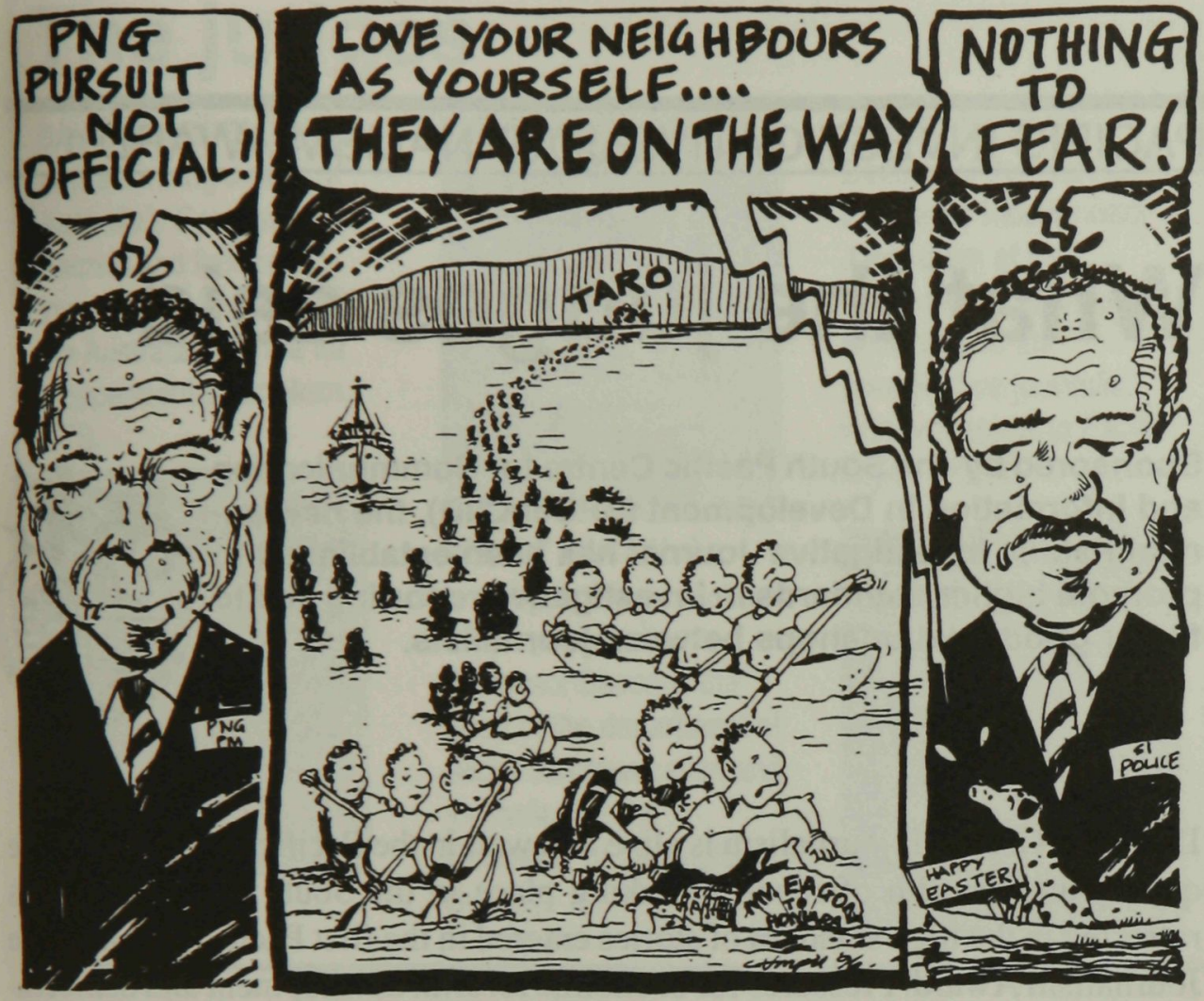

Solomons Voice, 4 April 1996: There was a mass exodus from the Choiseuls provincial town of Taro this week following warnings of PNG Defence Force incursions in what they claimed as 'hot pursuit' of BRA rebels. PNG Prime Minister Sir Julius Chan at the same time said such pursuit was 'not official' while Solomon Islands police said: 'There's nothing to fear.' 